\title{
Gerakan Budaya Cinta Lingkungan Untuk Mewujudkan Sekolah "BARA API"( Bersih, Asri, Rapi, Aman, Patuh, Dan Indah) Di Sekolah SMP Negeri 2 Pakem
}

\section{Tri Worosetyaningsih}

\author{
SMPN 2 Pakem \\ triworosetyaningsih@yahoo.co.id
}

\section{Article History}

accepted 01/12/2020

\begin{abstract}
The background of the environmental-loving cultural movement at SMP Negeri 2 Pakem because the school environment tends to be dirty, dry and arid, the school layout is not good, students commit vandalism, students tend to say badly and even impolite, lack awareness of obeying rules and regulations, and do not exist schedule and clean culture program at school. The movement to love the environment can make the school environment beautiful, comfortable while participating in the learning process, increase student creativity and literacy and create BARA API (Clean, Beautiful, Neat, Safe, Obedient, and Beautiful) schools. Other results can improve school achievement both academically and non academically for both students and teachers. The movement for a culture of loving the environment by focusing on improving the character of students, the school environment, and school management can create "BARA API" schools. The movement for a culture of loving the environment to make schools clean is evident in the increased awareness of students to throw garbage in its place, the responsibility of each student to clean the classroom and its environment increases, with the presence of a sink in each class in almost all rooms, the health of students is more guaranteed. Schools become beautiful and beautiful with reforestation programs, make gardens for each class and restore the function of land in the school environment.
\end{abstract}

Keywords: Movement, Culture of Love for the Environment, "Embers of Fire"

\begin{abstract}
Abstrak
Latar belakang Gerakan budaya cinta lingkungan di SMP Negeri 2 Pakem karena lingkungan sekolah yang cenderung kotor, kering dan gersang, tata ruang sekolah kurang baik, siswa melakukan vandalisme, siswa cenderung berkata tidak baik bahkan kurang sopan, kurangnya kesadaran mentaati tata tertib, dan belum ada jadwal serta program budaya bersih di sekolah. Gerakan cinta lingkungan dapat membuat lingkungan sekolah menjadi indah, nyaman saat mengikuti proses pembelajaran, kreativitas dan literasi siswa meningkat serta mewujudkan sekolah BARA API (Bersih, Asri, Rapi, Aman, Patuh, dan Indah). Hasil lain dapat meningkatkan prestasi sekolah secara akademik maupun non akademik baik siswa maupun guru. Gerakan budaya cinta lingkungan dengan memfokuskan pada peningkatan karakter siswa, lingkungan sekolah, dan manajemen sekolah dapat mewujudkan sekolah "BARA API". Gerakan budaya cinta lingkungan membuat sekolah menjadi bersih terbukti pada kesadaran siswa untuk membuang sampah pada tempatnya meningkat, tanggung jawab setiap siswa untuk membersihkan kelas dan lingkungannya meningkat, dengan adanya wastafel di tiap tiap kelas dihampir semua ruangan maka kesehatan siswa menjadi lebih terjamin. Sekolah menjadi Asri dan Indah dengan program penghijauan, membuat taman tiap kelas dan mengembalikan fungsi tanah di lingkungan sekolah.
\end{abstract}

Kata kunci: Gerakan Budaya Cinta Lingkungan, "BARA API"

Social, Humanities, and Education Studies (SHEs): Conference Series https://jurnal.uns.ac.id/shes

p-ISSN 2620-9284

e-ISSN 2620-9292 


\section{PENDAHULUAN}

Pendidikan karakter saat ini gencar dilaksanakan di sekolah sebagai wujud dari profil pelajar Pancasila. Pendidikan karakter untuk mewujudkan lingkungan Sekolah yang berkualitas sangat diperlukan agar tercipta sekolah yang bermutu. Pemberian pengetahuan, keterampilan, dan pembentukan kesadaran siswa tentang perilaku hidup yang baik dirasa sangat efektif ketika dilakukan pada siswa sejak di bangku sekolah. Diharapkan ketika berada di luar lingkungan sekolah, mampu menerapkan apa yang diperoleh di sekolah. Pembentukan karakter kadang terlupakan di sekolah dikarenakan biasanya pendidikan hanya berorientasi pada kecerdasan intelektual.

Budaya perilaku mencintai lingkungan merupakan perilaku hidup yang baik untuk pembentukan karakter siswa di sekolah. Karakter siswa sangat penting diperhatikan di sekolah karena dapat mendorong siswa untuk melakukan hal-hal yang baik. Penguatan Pendidikan Karakter yang diperlukan untuk mewujudkan kualitas lingkungan yang baik adalah disiplin, mandiri, tanggung jawab, religius, gotong royong, dan cinta tanah air. Budaya cinta lingkungan perlu dikembangkan dalam dunia pendidikan karena pada dasarnya semua anak menuntut ilmu, akan berjalan dengan baik apabila seiring munculnya berbagai kebijakan mengenai penanganan dan pengelolaan lingkungan yang baik. Lingkungan sekolah sangat berperan dalam pembentukan karakter pada siswa. Intensitas pertemuan yang hampir setiap hari dengan guru dan teman-teman sekolah tentunya membuat anak mencari-cari dirinya melalui hal yang dilihat, dirasakan, didengar, dan ditiru dari lingkungan sekitarnya. Hamzah B. Uno dan Nurdin Mohamad (2011: 136) menyebutkan bahwa penanamaman, pemahaman, dan kesadaran tentang pentingnya menjada kelestarian kualitas lingkungan sangat baik apabila mulai diterapkan melalui pendidikan. Pendidikan menjadi pilihan dan sasaran yang tepat untuk penanaman karakter, salah satunya adalah membentuk karakter cinta lingkungan. Konsep pelaksanaan pendidikan cinta lingkungan mengacu pada konsep pendidikan karakter, karena pendidikan cinta lingkungan termasuk dalam upaya pengembangan pendidikan karakter.

Kondisi lingkungan sekolah akan sangat mempengaruhi proses kegiatan pembelajaran, proses pembelajaran akan mempengaruhi hasil belajar peserta didik. Peran penting lingkungan sekolah dalam proses pendidikan diharapkan mampu menjadi tempat yang mendukung dalam proses pendidikan yang sudah direncanakan. Lingkungan sekolah disini yang dimaksud adalah lingkungan yang bersih, asri, rapi, aman, patuh, dan indah. Di lingkungan sekolah peserta didik dapat langsung diajarkan tentang bagaimana berinteraksi dengan lingkungan, menjaga lingkungan, dan melestarikan lingkungan. Pembelajaran tersebut tidak hanya dalam keseharian tetapi juga diterapkan dalam bahan ajar yang dibuat oleh guru. Dalam pembelaharan yang mengedepankan budaya cinta lingkungan, dengan sendirinya nilai nilai karakter dapat tertanam dalam diri peserta didik. Ada beberapa indikator yang harus dicapai oleh sekolah dalam rangka menanamkan nilai karakter cinta lingkungan. Menurut Pupuh Fathurrohman, dkk (2013: 191) indikator yang harus dicapai adalah sebagai berikut : 1) Pembiasaan memelihara kebersihan dan kelestarian lingkungan sekolah, 2) Tersedia tempat pembuangan sampah dan tempat cuci tangan, 3) Menyediakan kamar mandi dan air bersih Pembiasaan hemat energi, 4) Membuat biopori di area sekolah, 5) Membangun saluran pembuangan air limbah dengan baik, 6)Melakukan pembiasaan memisahkan jenis sampah organik dan anorganik, 7)Penugasan pembuatan kompos dari sampah organik, 8)Menyediakan peralatan kebersihan. Selain indikator yang harus dicapai dan dikembangkan oleh sekolah dalam penanaman karakter, sekolah juga harus didukung oleh seluruh pihak warga sekolah bahkan komite dan masyarakat. Salah satu pihak yang berperan penting dalam program penanaman karakter cinta 
lingkungan yaitu kepala sekolah dan guru. Program sekolah yang sudah diputuskan harus mampu direalisasikan melalui guru untuk diperkenalkan kepada peserta didik. Oleh karena itu ada beberapa indikator yang harus dicapai oleh setiap kelas dalam rangka penanaman karakter cinta lingkungan. Menurut Dalyono (2010:131) lingkungan sekolah merupakan salah satu faktor yang turut mempengaruhi pertumbuhan dan perkembangan anak terutama untuk kecerdasannya. Lingkungan sekolah sangat berperan dalam meningkatkan pola pikir anak, karena kelengkapan sarana dan prasarana dalam belajar serta kondisi lingkungan yang baik sangat penting guna mendukung terciptanya lingkungan belajar yang menyenangkan. Lingkungan sekolah yaitu keadaan sekolah tempat belajar yang turut mempengaruhi tingkat keberhasilan belajar. Keadaan gedung sekolahnya dan letaknya, serta alat-alat belajar yang juga ikut menentukan keberhasilan belajar siswa. Agar kondisi tersebut dapat terwujud dengan baik perlu dilakukan gerakan bersama yang dilaksanakan secara rutin yaitu gerakan cinta lingkungan.

Gerakan Budaya Cinta lingkungan sangat diperlukan di SMPN 2 Pakem untuk mewujudkan sekolah "BARA API" (Bersih, Asri, Rapi, Aman, Patuh, dan Indah) yang merupakan visi lingkungan sekolah. Hasil pengamatan kondisi awal lingkungan sekolah SMP Negeri 2 Pakem saat awal menjabat Kepala Sekolah pada bulan September tahun 2016 diperoleh (1)Lingkungan sekolah yang cenderung kotor karena banyak ditemui sampah terutama bungkus makanan, siswa kurang memiliki kesadaaraan untuk membuang sampah pada tempatnya. mereka membuang sampah seenaknya dilingkungan sekolah tanpa memiliki beban apapun, (2) Sekolah terkesan kering dan gersang karena sebagian besar lingkungan sekolah disementasi atau di konblock, (3)Tata ruang sekolah kurang baik sehingga terkesan kumuh. (4)Siswa banyak yang melakukan vandalisme di tembok-tembok lingkungan sekolah dan meja. Dari hasil pengamatan, yang paling banyak di coret coret siswa yaitu di kamar mandi dan meja siswa. (5)Siswa terbiasa berkata tidak baik bahkan kurang sopan terhadap orang lain (6) Kurangnya kesadaran siswa untuk mentaati tata tertib sekolah. (7) Belum ada jadwal dan program khusus untuk budaya bersih di sekolah, hanya siswa diminta piket sesuai jadwal harian.

Kondisi awal lingkungan di SMPN 2 Pakem

\section{HASIL DAN PEMBAHASAN}

Kondisi-kondisi di atas yang mempengaruhi kualitas lingkungan dan sumber daya manusia yang ada di SMPN 2 Pakem dan tidak sesuai dengan visi dan misi sekolah yang ditetapkan. Hal tersebut yang melatarbelakangi sekolah untuk membuat suatu program gerakan budaya cinta lingkungan. Untuk mengatasi permasalahanpermasalahan yang ada terutama yang dilakukan terlebih dahulu yaitu meningkatkan kondisi kualitas lingkungan sekolah antara lain 1) Menanam pohon perindang di semua sisi sekolah sehingga menjadi lebih rindang, 2) Mengembalikan fungsi tanah sebagai tumbuhnya tanaman dengan membongkar sementasi dibeberapa tempat, 3) Menata ruang sekolah sehingga tidak terkesan kumuh, 4) memberdayakan warga sekolah untuk budaya kebersihan sekolah dengan membuat jadwal khusus setiap hari, 5) Kebijakan satu siswa satu tanaman hias dan satu tanaman toga, 6)Memperbaiki manajemen pengelolaan sekolah. 7) Memasukkan gerakan budaya cinta lingkungan di dalam Kurikulum Sekolah dan 8) Memasukkan gerakan budaya cinta lingkungan dalam pembiasaan, pembelajaran dan ektrakurikuler. Yang tidak kalah penting menanamkan kepada siswa untuk memiliki tanggungjawab dan secara mandiri dapat menggelola lingkungan sekolah dengan menyiram, menyapu lingkungan kelas, menanam pohon, mengepel lantai, membersihkan kamar mandi dan sebagainya. 
Dalam begitu tujuan dari gerakan cinta lingkungan sekolah akan akan terwujud dan kondisi lingkungan sekolah semakin baik.

Stategi Implementasi

Strategi Implementasi Gerakan budaya cinta lingkungan dalam peningkatan karakter siswa, sarana prasarana sekolah, dan manajemen sekolah. Selain itu dimasukkan dalam pembiasaan, proses pembelajaran dan ekstrakurikuler untuk mewujudkan sekolah yang Bersih, Asri, Rapi, Aman, Patuh, dan Indah (BARA API) sesuai dengan visi lingkungan sekolah sebagai berikut

\section{Sekolah bersih}

Kebersihan sebuah lingkungan dapat mencerminkan kepribadian orang-orang yang tinggal atau menetap pada lingkungan tersebut, contohnya seperti halaman sekolah selalu bersih, maka akan menunjukkan kepribadian para penghuni sekolah yang rajin dan mempunyai nilai keindahan yang tinggi terhadap diri maupun lingkungannya. Hidup bersih akan berdampak pada jiwa kita, contohnya jika sekolah kita bersih maka hati kita akan senang dan terasa betah di sekolah, demikian juga jika suasana kelas, lingkungan sekolah bersih maka suasana belajar akan terasa lebih nyaman dan enak, sehingga hasil belajar akan lebih maksimal. Gerakan budaya cinta lingkungan di SMP Negeri 2 Pakem terbukti pada kesadaran siswa untuk membuang sampah pada tempatnya meningkat, tanggung jawab setiap siswa untuk membersihkan kelas dan lingkungannya, adanya wastafel di tiap tiap kelas dan hampir semua ruangan untuk budaya cusi tangan setiap beraktivitas maka kesehatan siswa menjadi lebih terjamin. Kondisi tersebut menyebabkan siswa saat datang ke sekolah, saat pembelajaran maupun saat istirahat dengan riang gembira bercengkrama di halaman maupun di sudut taman taman sekolah.

\section{Sekolah Asri}

Lingungan asri dapat diartikan sebagai lingkungan yang penataan dan pengelolaannya menjadikan lingkungan tersebut indah dan sedap dipandang oleh setiap orang yang melihat. Asri juga berkaitan erat dengan vegetasi (tanaman). Sehingga lingkungan yang asri bukan sekedar indah dan sedap dipandang melainkan juga mempunyai vegetasi yang menyatu dan tertata dengan baik. Di SMP Negeri 2 Pakem Program penghijauan dengan membuat taman tiap kelas, taman paguyuban, membuat hutan sekolah, menanam pohon buah dan pohon lain di setiap lahan yang ada di sekolah, menanam toga dan sayuran di lahan lahan kosong, dan mengembalikan fungsi tanah di lingkungan sekolah. Dengan program ini terbukti menambah situasi kondusif di dalam proses KBM, serta menambah kenyamanan seluruh warga sekolah, serta mengurangi asap polusi yang ada di sekolah. Kondisi tersebut tercipta lingkungan yang asri. Warga sekolah dengan lingkungan asri dapat menghirup udara yang sejuk dan segar sehingga akan menciptakan rasa nyaman bagi kehidupan yang ada di dalamnya.

\section{Sekolah rapi}

Kerapian adalah suasana harmonis dan selaras dalam diri kita dengan orang lain, keluarga, sekolah, kantor, atau lingkungan sekitar. Indikator sekolah yang rapi yaitu tidak ada sampah berserakan, banyak pepohonan, tidak membuang sampah ke sungai, selokan bersih dan tidak membuang sampah sembarangan. Lingkungan yang rapi dapat memberikan manfaat antara lain a)Lingkungan yang bersih akan menjauhkan sumber-sumber penyakit untuk berkembang di sekitar kita dan b) para penghuninya nyaman dan kesehatan tubuhnya terjaga dengan baik. 
Adapun Gerakan cinta lingkungan di SMP Negeri 2 Pakem telah membuat sekolah menjadi rapi, Siswa mentaati tata tertib sekolah seperti berpakaian rapi lengkap dengan atributnya, rapi dalam menata ruang kelas, rapi dalam melaksanakan kegiatan pembiasaan seperti upacara setiap hari senin, senam tiap hari jumat. Perilaku rapi dari siswa memberikan dampak semakin berkurangnya siswa yang melakukan pelanggaran. Selain itu manajemen sekolah yang baik membuat gedung dan sarana lain menjadi rapi dan tertata dengan baik. Terbukti ruangan yang fungsinya kurang dan menambah kurang nyaman dikembalikan fungsi awalnya. Lahan yang kurang bermanfaat di fungsikan menjadi taman, pajangan hasil kreativitas siswa tertata dengan baik begitu juga dengan poster dan selogan yang dipajang di dinding sekolah.

\section{Sekolah Aman}

Secara mudah pengertian aman adalah kondisi dimana kita bisa mengidentifikasi resiko yang ada dan mengurangi resiko seminimal mungkin ke level yang bisa diterima. Dengan kata lain Aman adalah situasi dimana seseorang bebas dari bahaya dan rasa takut. Dengan demikian, sekolah aman adalah lembaga pendidikan yang warganya bebas dari bahaya baik secara internal maupun eksternal. Dengan adanya gerakan cinta lingkungan dapat menimbulkan rasa aman bagi warga sekolah terbukti sopan santun siswa meningkat, berkurangnya bahkan tidak ada lagi siswa yang berani dengan guru, siswa apabila bertemu dengan bapak ibu guru dan karyawan bahkan tamu di sekolah mereka memberikan salam, tidak berkata kurang pantas dengan temannya, dan tidak emosional apabila ada perselisihan dengan orang lain. Kondisi ini menimbulkan keharmonisan dilingkungan warga sekolah. Dengan keharmonisan tersebut maka akan timbul rasa aman diantara warga sekolah.

\section{Patuh}

kepatuhan merupakan tindakan memenuhi permintaan orang lain, didefinisikan sebagai suatu tindakan atau perbuatan yang dilakukan berdasarkan keinginan orang lain atau melakukan apa-apa yang diminta oleh orang lain, kepatuhan mengacu pada perilaku yang terjadi sebagai respons terhadap permintaan langsung dan berasal dari pihak lain. jika siswa patuh pada tata tertib sekolah maka akan membentuk karakter yang disiplin dan bertanggung jawab sehingga dapat dipercaya, menciptakan suasana yang damai dan tentram, dan segala kegiatan dapat berjalan dengan lancar.

Dengan adanya gerakan cinta lingkungan di SMP Negeri 2 Pakem maka tatatertib sekolah ditegakkan disertai dengan sangsi yang mendidik didukung dengan adanya kesepakatan kelas yang dibuat atas persetujuan bersama antar siswa dengan sepengetahuan orang tua. Kondisi ini dapat meningkatkan kepatuhan siswa, hal ini terbukti (1) tidak adalagi siswa yang ke sekolah mengerombol dan nongkrong. Mereka begitu sampai di depan halaman sekolah bergegas masuk. (2) siswa yang terlambat ke sekolah berkurang bahkan sering tidak ada meskipun sekolah mulai masuk jam 6.50 WIB. (3) siswa tidak membuang sampah disembarang tempat, hal ini karena kesadaran siswa akan kebersihan lingkungan sekolah. Hasil wawancara dengan beberapa siswa yang mengatakan sangat senang dengan lingkungan sekolah yang sekarang. (4) siswa patuh terhadap jadwal piket kelas maupun budaya bersih yang sudah jelas pembagiannya, bahkan mereka melaksanakan dengan senang hati karena setiap hari pada saat jadwal budaya bersih semua warga sekolah membersihkan lingkungan.

\section{Sekolah Indah}

Indah artinya dalam keadaan enak dipandang, cantik dan elok dalam sekolah sangat diperlukan. Manusia memiliki sensibilitas esthetis, karena itu manusia tak dapat 
dilepaskan dan keindahan. Manusia membutuhkan keindahan dalam kcsempurnaan (keutuhan) pribadinya begitu juga dengan siswa. Dengan kondisi sekolah yang indah membuat siswa menjadi nyaman di sekolah, siswa akan merasa senang berasa sekolah dan nantinya dapat berimbas pada peningkatan kualitas. Lingkungan sekolah merupakan wahana siswa dalam belajar. Lingkungan sekolah sebagai salah satu tempat sumber belajar harus menciptakan rasa senang. Salah satu cara untuk menciptakan rasa senang di sekolah dengan menciptakan keindahan.

Gerakan cinta lingkungan dapat membuat lingkungan menjadi indah hal ini dapat membangkitkan semangat para siswa dan guru dalam menciptakan rasa betah dan nyaman saat menjalankan kegiatan belajar mengajar (KBM) di sekolah. Lingkungan sekolah yang indah didukung dengan kelas yang di buat seindah mungkin dapat menimbulkan rasa senang ,kreativitas meningkat, dan literasi siswa. Gerakan cinta lingkungan di sekolah berpedoman pada indikator sekolah ramah anak dan Adiwiyata dengan demikian kebutuhan dan layanan terhadap warga sekolah dapat terpenuhi. Dalam penerapan gerakan budaya cinta lingkungan untuk mewujudkan sekolah "BARA API"( Bersih, Asri, Rapi, Aman, Patuh, dan Indah) tentunya ada faktor pendukung dan faktor penghambat.

\section{Faktor pendukung}

Secara strategis terletak dikawasan objek wisata kaliurang sehingga lingkungan mendukung. Kaliurang merupakan kawasan Gumung Merapi yang sejuk, segar dan pemandangannya indah. Karena berada di kawasan Gunung Merapi maka jenis tanahnya tanah vulkanik yang subur. Sekolah memiliki luas lahan kurang lebih $7.200 \mathrm{~m}^{2}$ sehingga sangat mendukung untuk penghijauan sekolah Komite sekolah yang solid sehingga mendukung program sekolah Warga sekolah yang memiliki loyalitas tinggi sehingga mendukung program sekolah. Dukungan dari masyarakat di sekitar lingkungan sekolah Dinas pendidikan dan istansi terkait memberikan dukungan moril .

Faktor penghambat yang harus diatasi

Kondisi kesadaran siswa untuk menjaga lingkungan sekolah dengan baik yang masih kurang; Kondisi sekolah yang kesulitan air karena terletak di daerah pegunungan sehingga sumber air sangat dalam; Kondisi keluarga siswa yang sebagian besar bermasalah sehingga mempengaruhi perilaku negatif siswa ; Lingkungan objek wisata dengan berbagai macam tempat hiburan dan perilaku negatif yang ada di dalamnya sangat mempengaruhi perilaku siswa dan Manajemen sekolah yang masih belum baik.

Dampak dalam penerapan gerakan budaya cinta lingkungan untuk mewujudkan sekolah "BARA API"( Bersih, Asri, Rapi, Aman, Patuh, dan Indah) adalah

1. Kebersihan Sekolah Meningkat (bersih)

Sekolah telah membuat beberapa program untuk meningkatkan kebersihan sekolah yaitu Piket harian siswa, Penjadwalan budaya bersih setiap hari, Jumat bersih, dan Lomba Kebersihan Kelas. Dengan program program sekolah tersebut membuat sekolah menjadi bersih. Kebersihan sekolah juga didukung oleh kesadaran siswa untuk membuang sampah pada tempatnya juga meningkat. Mereka sadar bahwa sekolah yang bersih membuat mereka nyaman di sekolah. Siswa saat datang ke sekolah maupun saat istirahat dengan riang gembira bercengkrama di halaman maupun di sudut taman taman sekolah. 

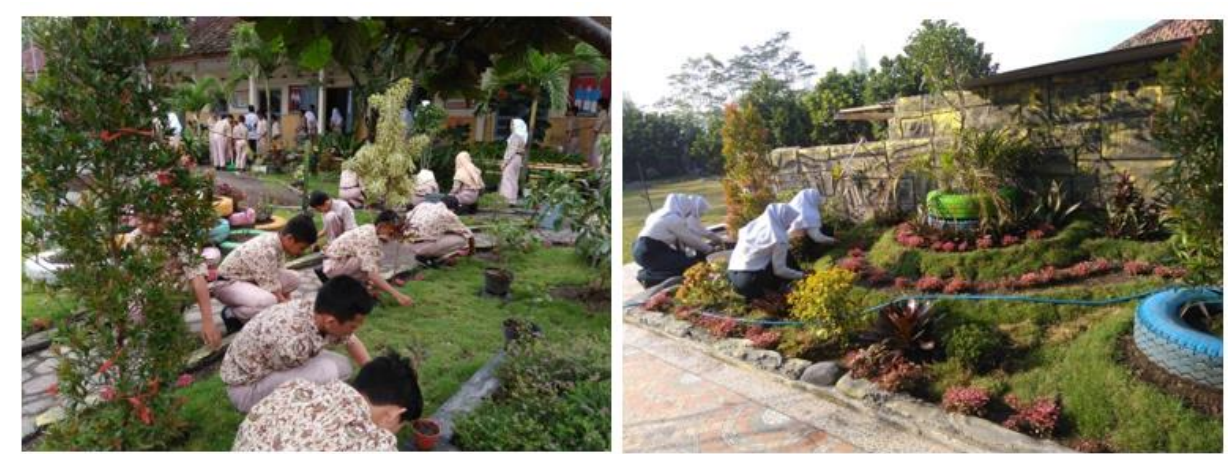

Gambar 1. Siswa melakukan kegiatan budaya bersih setiap hari

Siswa sebelum gerakan budaya cinta lingkungan sering membawa makanan dan minuman ke dalam kelas karena tidak memiliki kantin yang representatif. Setelah membuatan kantin sekolah sesuai standar dan jauh dari kelas dengan standar makanan dan minuman yang sudah ditetapkan sekolah maka kebersihan menjadi lebih terjamin. Sebelum kepala sekolah menjabat, kondisi sekolah belum ada wastafel atau tempat cuci tangan. Karena menyadari pentingnya sarana tersebut dengan bantuan dari komite yang merupakan perwakilan siswa maka sekolah membuat wastafel. Tujuan di adakannya pembuatan wastafel agar siswa selalu menjaga kebersihan saat memulai aktivitas maupun sesudahnya dengan demikian akan terjaga kesehatannya sehingga dalam mengikuti pembelajaran menjadi semangat.

2. Sekolah Menjadi Asri

Selama kepala sekolah menjabat dan sudah melakukan observasi selama beberapa bulan maka kepala sekolah melakukan kebijakan penghijauan di sekolah. Program yang dilakukan antara lain dengan membuat taman taman tiap kelas dan mengembalikan fungsi tanah sebagai tempat tumbuhnya tanaman dengan membongkar sementasi di lingkungan sekolah. diadakan penghijauan ini juga bertujuan utuk menambah situasi yang kondusif didalam proses KBM, serta menambah kenyamanan seluruh warga sekolah, serta mengurangi asap polusi yang ada di sekolah. Memberikan kesadaran kepada siswa tentang pentingnya memperhatikan kondisi lingkungan sekolah sehingga tercipta lingkungan yang asri dengan udara yang sejuk. Menghirup udara yang sejuk dan segar merupakan suatu bentuk kenikmatan untuk menikmati keindahan alam. Dengan kondisi lingkungan alamnya yang asri dan hijau akan menciptakan rasa nyaman bagi kehidupan yang ada di dalamnya. Seperti yang telah kita ketahui bahwa hidup ini bergantung pada alam, jika kondisi alamnya baik, maka kehidupan yang ada di dalamnya pun akan baik. Lingkungan sekolah merupakan tempat tinggal yang kedua bagi siswa yang perlu diperhatikan kondisi lingkungan alamya. Dengan tiap kelas di beri tanggung jawab taman, mereka jadi punya jiwa memiliki dan memiliki kepedulian untuk membuat taman kelasnya menjadi yang terbaik 

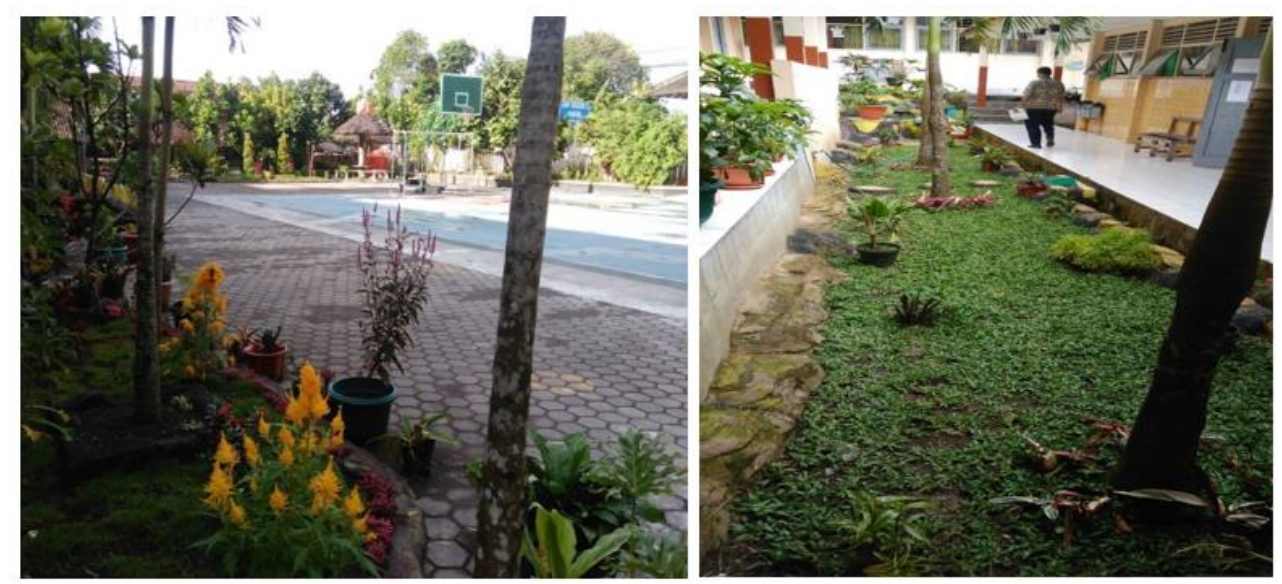

Gambar 2. Tamanisasi di hampir semua tempat lingkungan sekolah

3. Sekolah Menjadi Rapi

Gerakan cinta lingkungan telah membuat sekolah menjadi rapi baik dari warga sekolah maupun lingkungan sarana sekolah. Siswa mentaati tata tertib sekolah seperti dengan berpakaian rapi lengkap dengan atributnya, rapi dalam menata ruang kelas, rapi dalam melaksanakan kegiatan pembiasaan seperti upacara setiap hari senin, senam tiap hari jumat.
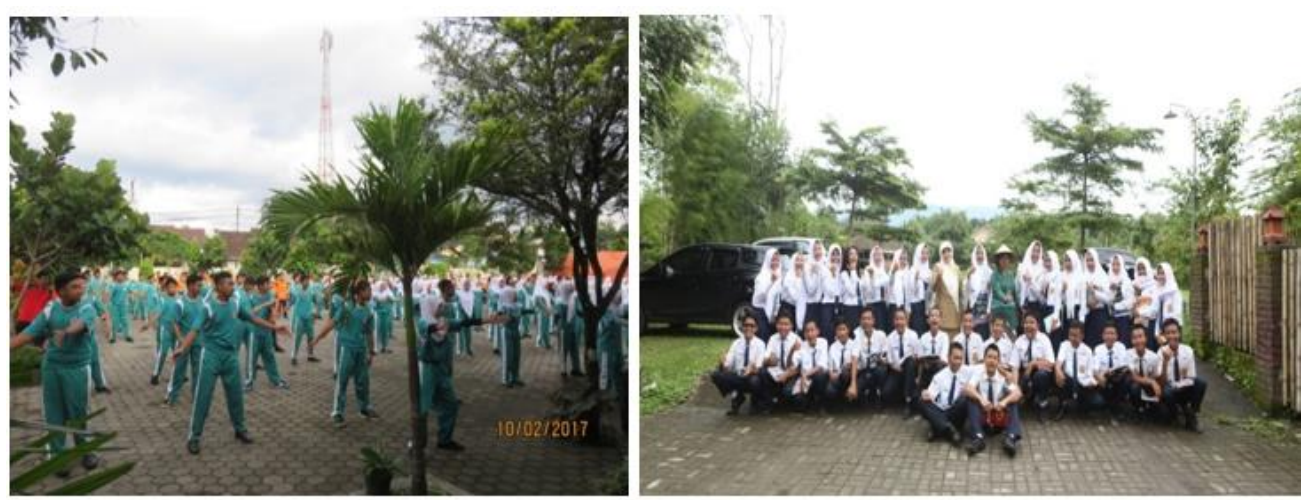

Gambar 3. Kondisi siswa yang rapi

Dengan perilaku rapi dari siswa memberikan dampak yang baik untuk sekolah terbukti dengan semakin berkurangnya siswa yang melakukan pelanggaran sehingga sekolah semakin tentram dan nyaman. Dengan manajemen sekolah yang baik membuat gedung dan sarana lain menjadi rapi dan tertata dengan baik. Terbukti ruangan yang fungsinya kurang dan menambah kurang nyaman dikembalikan fungsi awalnya. Lahan lahan yang kurang bermanfaat di fungsikan menjadi taman, pajangan hasil kreativitas siswa tertata dengan baik begitu juga dengan poster dan selogan yang dipajang di dinding sekolah. Dengan sekolah yang rapi menambah cinta siswa terhadap lingkungannya baik di sekolah mauun di masyarakat.

4. Sekolah Menjadi Aman

Dengan adanya gerakan cinta lingkungan dapat menimbulkan rasa aman bagi warga sekolah karena Sopan santun siswa meningkat terbukti siswa tidak ada yang 
berani dengan guru, siswa apabila bertemu dengan bapak ibu guru dan karyawan bahkan tamu di sekolah mereka memberikan salam, tidak berkata kurang pantas dengan temannya, dan tidak emosional apabila ada perselisihan dengan orang lain. Kondisi ini menimbulkan keharmonisan dilingkungan warga sekolah. Dengan keharmonisan tersebut maka akan timbul rasa aman diantara warga sekolah.
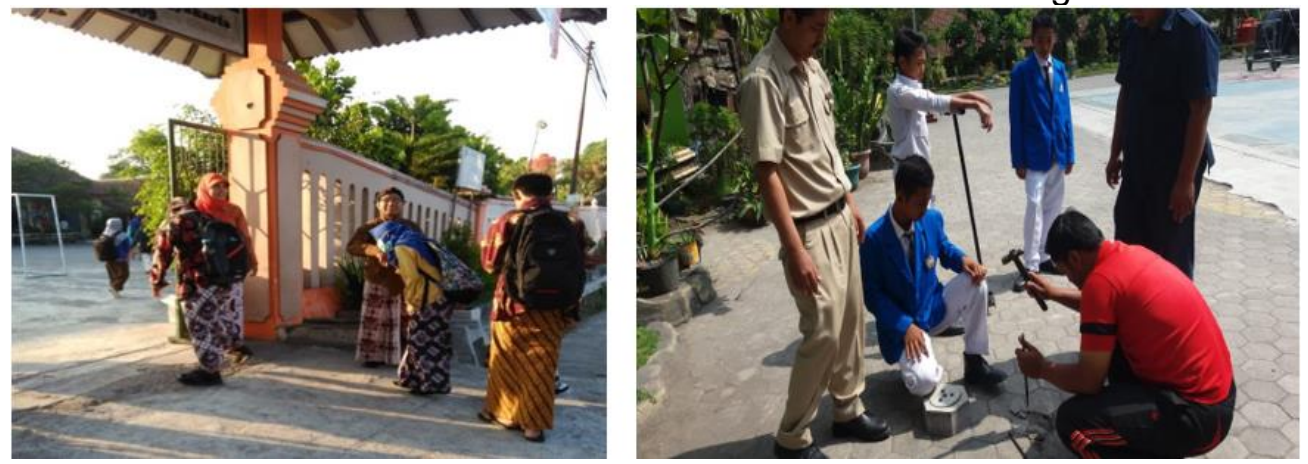

\section{Gambar 4. Pembiasaan $5 \mathrm{~S}$ dan guru dengan siswa bersama sama memperbaiki lingkungan sekolah}

5. Siswa lebih Patuh atau disiplin

Tata tertib sekolah sudah dibuat sejak sekolah berdiri dan terus mengalami perkembangan namun pelaksanaannya kurang begitu diterapkan dengan tegas, hanya sekedar formalitas bahkan tidak ada sangsi apapun bagi siswa yang melanggar. Dengan adanya gerakan cinta lingkungan maka tatatertib sekolah ditegakkan disetai dengan sangsi yang mendidik didukung dengan adanya kesepakatan kelas yang dibuat atas persetujuan bersama antar siswa dengan sepengetahuan orang tua. Kondisi ini dapat meningkatkan keparuhan dan disiplin siswa, hal ini terbukti (1) tidak adalagi siswa yang ke sekolah mengerombol dan nongkrong. Mereka begitu sampai di depan halaman sekolah bergegas masuk. (2) siswa yang terlambat ke sekolah berkurang bahkan sering tidak ada meskipun sekolah mulai masuk jam 6.50 WIB. (3) siswa tidak membuang sampah disembarang tempat, hal ini karena kesadaran siswa akan kebersihan lingkungan sekolah. Mereka sangat senang bermain dan bercanda ria sambil duduk-duduk di taman sekolah yang bersih. Hal ini dibuktikan dari hasil wawancara dengan beberapa siswa yang mengatakan sangat senang dengan lingkungan sekolah yang sekarang. (4) siswa patuh terhadap jadwal piket kelas maupun budaya bersih yang sudah jelas pembagiannya, bahkan mereka melaksanakan dengan senang hati karena setiap hari pada saat jadwal budaya bersih semua warga sekolah membersihkan lingkungan.
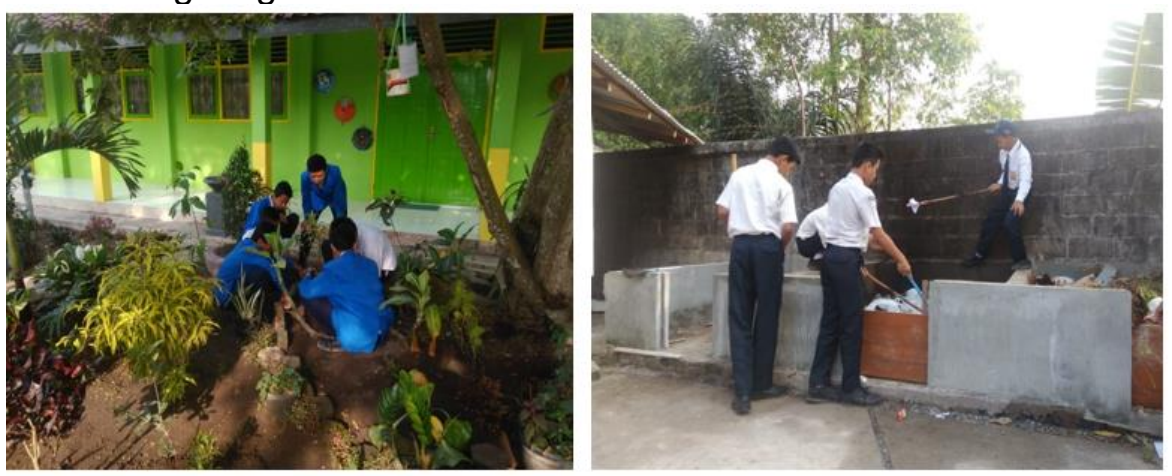

Gambar 5. Siswa Menanam Pohon Dan Memilah Sampah 
6. Sekolah menjadi Indah

Lingkungan yang indah diharapkan mampu membangkitkan semangat para siswa dan guru dalam menciptakan rasa betah dan nyaman saat menjalankan kegiatan belajar mengajar (KBM) di sekolah. Indahnya lingkungan sekolah merupakan dambaan semua warga sekolah. Dengan usaha keras untuk membuat sekolah menjadi indah untuk di pandang maka siswa memiliki rasa tanggung jawab untuk memper indah sekolah. Dengan kondisi sekolah yang indah ditambah asri membuat tamu menjadi senang dan nyaman datang ke sekolah. Mereka ingin melihat melihat dan berfoto.

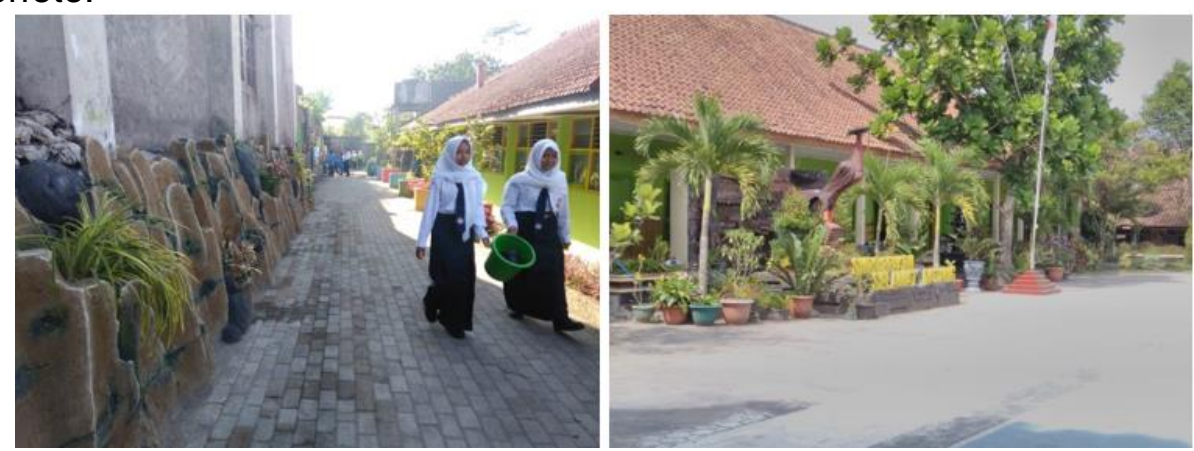

Gambar 6. Lingkungan sekolah yang asri dan mnyenangkan

Lingkungan sekolah yang indah didukung dengan kelas yang di buat seindah mungkin dengan lukisan-lukisan hasil karya mereka. Dengan demikian mereka selain senang berada di sekolah, juga menikmati suasana yang berbeda.
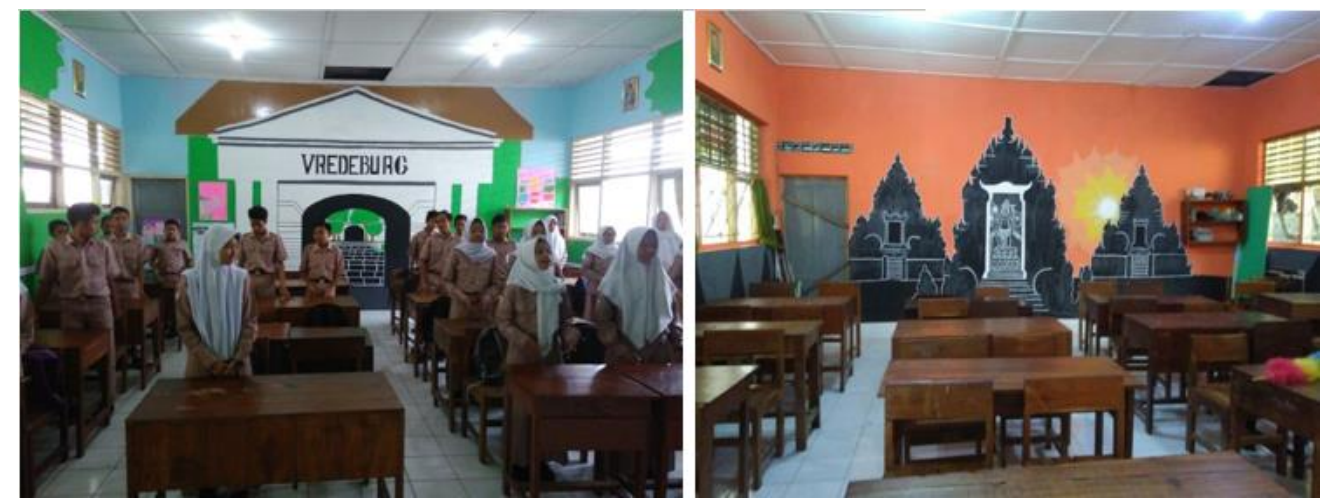

Gambar 7. Lukisan tiap-tiap kelas dengan tema objek wisata

Dengan gerakan budaya cinta lingkungan selain terwujudnya sekolah "BARA API" yang tidak kalah penting adalah dampak dari gerakan tersebut yaitu

1. Karakter Siswa meningkat

Saat ini penguatan pendidikan karakter sangat penting dilakukan di sekolah karena makin berkurangnya nilai nilai karakter siswa akibat pengaruh lingkungan terutama di era globaliasi. Dengan adanya gerakan budaya cinta lingkungan akan menumbuhkan pula budaya karakter siswa baik di lingkungan sekolah maupun di luar sekolah. Hal ini menimbulkan perubahan luar biasa bagi siswa. Nilai-nilai karakter yng muncul terutama religius karena mereka meyakini kebersihan merupakan bagian dari Iman, disiplin karena mereka patuh terhadap tatatertib sekolah, peduli lingkungan karena saat ini setiap hari disekolah siswa memiliki 
tanggung jawab terhadap lingkungannya, dan tanggung jawab karena setiap siswa memiliki kewajiban untuk membuat lingkungan sekolah menjadi semakin baik.

2. Kreativitas siswa meningkat

Gerakan budaya cinta lingkungan dapat meningkatkn kreativitas siswa di sekolah sehingga dapat mewujudkan Sekolah "BARA API" terutama rapi dan indah. Secara terjadwal setiap minggu ada kegiatan lomba kreativitas dengan memanfaatkan barang bekas. Selain itu setiap ada peringatan hari-hari besar, ulang tahun sekolah bahkan setelah selesai penilaian juga diadakan lomba baik individu maupun antar kelas yang melibatkan semua siswa. Kegiatan tersebut selain meningkatkan kreativitas siswa juga akan menimbulkan jiwa kompetisi diantara siswa. Hal tersebut dibuktikan dengan adanya gelar kreativitas siswa sesuai budaya lokal, pajangan hasil kreativitas di lingkungan sekolah, dan taman siswa yang dibuat dengan kreativitas siswa. Semua lomba yang diadakan di sekolah disertai dengan penghargaan bagi yang menang.

3. Siswa lebih mencintai budaya local

Dengan lingkungan yang baik dan harmonis, memberikan dampak yang baik dalam penguatan karakter siswa terutama mencintai budaya Indonesia terutama budaya lokal yaitu Jawa. Siswa sudah terbiasa dengan pakaian adat Jawa, tarian tarian jawa, makanan dan semua yang bernuansa jawa. Bahkan saat ini di semua kegiatan harus menggunakan bahasa Jawa. Selain cinta dengan budaya Jawa, siswa juga sangat mencintai lingkungan geografis daerah lingkungan sekolah dan tempat tinggal yang terletak di lereng gunung merapi. Hal ini terbukti lukisan moral di kelas dan taman yang mengambarkan kondisi lingkungannya.

4. Kebersamaan Paguyuban orang tua untuk memajukan sekolah meningkat

Gerakan cinta lingkungan tidak hanya menjadi tanggungjawab warga sekolah, namun orang tua siswa juga ikut andil di dalamnya. Orang tua juga ikut memiliki sekolah sehingga mempunyai kewajiban untuk memperbaiki lingkungan sekolah. Mereka bergotong royong membantu membuat taman untuk putra putri mereka. Selain membuatkan taman juga secara terjadwal membersihkan dan merawat taman dan lingkungan kelas. Mereka dengan semangat membuat lingkungan sekolah menjadi bersih. Gerakan budaya cinta lingkungan telah membuat persaudaraan antar orang tua menjadi meningkat.
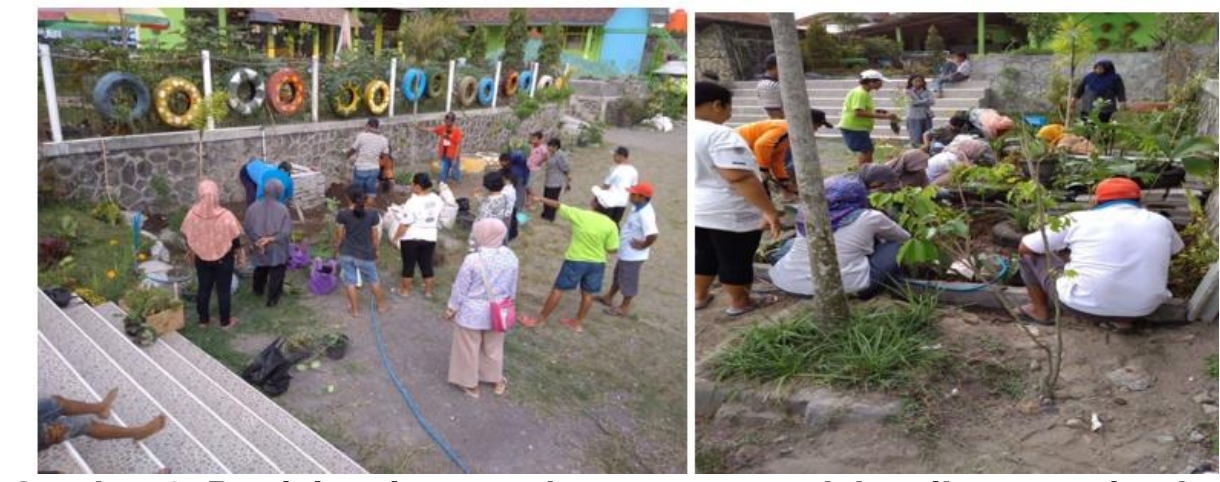

Gambar 8. Partisipasi paguyuban orang tua dalam ikut menciptakan

5. Prestasi sekolah meningkat lingkungan sekolah yang Asri

Dengan gerakan budaya cinta lingkungan maka dapat mewujudkan sekolah BARA API (Bersih, Asri, Rapi, Aman, Patuh, dan Indah) selain itu ternyata dapat meningkatkan prestasi sekolah baik akademik maupun non aka demik baik siswa maupun guru selama kepala sekolah menjabat selama satu tahun.

a. Prestasi siswa 
1) Nilai hasil Ujian Nasional dari tahun ke tahun mengalami peningkatan.

2) Juara 2 telling story

3) Juara 2 mengambar poster tingkat kabupaten

4) Juara satu tekwondo dari tingkat kabupaten sampai nasional

b. Prestasi guru dan kepala sekolah

1) Juara olimpiae guru nasional tingkat kabupaten

2) Juara guru berprestasi tingkat provinsi dan finalis nasional

3) Kepala sekolah prestasi tingkat kabupaten Sleman

4) Juara naskah terbaik best practice kepala sekolah tingkat nasional

c. Prestasi sekolah

1) Juara 1 sekolah ramah anak tingkat kabupaten

2) Juara 1 sekolah Adiwiyata tk kabupaten

3) Juara 1 Sekolah siaga kependudukan

4) Jiara 1 PIK r

5) Juara 2 sekolah Adiwiyata tingkat provinsi

6) Juara 2 sekolah aman bencana

\section{SIMPULAN}

Gerakan budaya cinta lingkungan dengan memfokuskan pada peningkatan karakter siswa, lingkungan sekolah, dan manajemen sekolah dapat mewujudkan sekolah "BARA API" "( Bersih, Asri, Rapi, Aman, Patuh, dan Indah). Gerakan budaya cinta lingkungan membuat sekolah bersih terbukti pada kesadaran siswa untuk membuang sampah pada tempatnya meningkat, tanggung jawab setiap siswa untuk membersihkan kelas dan lingkungannya, dengan adanya wastafel di tiap tiap kelas dihampir semua ruangan maka kesehatan siswa menjadi lebih terjamin. Sekolah menjadi Asri dan Indah dengan program penghijauan, membuat taman tiap kelas dan mengembalikan fungsi tanah di lingkungan sekolah. Dengan program ini terbukti menambah situasi kondusif di dalam proses KBM, serta menambah kenyamanan seluruh warga sekolah, serta mengurangi asap polusi yang ada di sekolah. Sekolah menjadi rapi dengan siswa mentaati tata tertib sekolah dan perilaku rapi dari siswa memberikan dampak semakin berkurangnya siswa yang melakukan pelanggaran. Gerakan cinta lingkungan dapat menimbulkan rasa aman dan patuh bagi warga sekolah

\section{DAFTAR PUSTAKA}

Uno, H. B. dan Nurdin Mohamad. 2011. Belajar dengan Pendekatan PAILKEM.

Zulhijrah, Z. (2015). Implementasi Pendidikan Karakter di Sekolah. Tadrib, 1(1), 118136.

Fathurrohman, Pupuh.dkk.2013 Pengembangan Pendidikan Karakter. Bandung: PT Refika Aditama. 